\title{
Cephalopod Species in Mozambican Waters Caught in the "Mozambique 0307" Survey: Distribution, Abundance and Assemblages
}

\author{
Luis Silva', Eduardo Balguerías ${ }^{2}$, Paula Santana Afonso ${ }^{3}$, Ignacio Sobrino' ${ }^{1}$, Juan Gil ${ }^{1}$ and \\ Candelaria Burgos ${ }^{1}$ \\ ${ }^{I}$ Instituto Español de Oceanografía Unidad de Cádiz. Muellle Pesquero s/n Apdo. 2906. 11006 Cádiz, Spain; \\ ${ }^{2}$ Instituto Español de Oceanografia. Centro Oceanogáfico de Canarias. Apdo. 1373.38120 Santa Cruz de \\ Tenerife, Spain; ${ }^{3}$ Instituto de Investigaçao Pesqueira. Avda Mao Tse Tung. Maputo, Mozambique
}

Keywords: Mozambican waters, assemblages cephalopods, shelf community, upper-middle slope

\begin{abstract}
The present paper reports for the first time for Mozambique waters the distribution, abundance and species assemblages of cephalopods in the outer shelf and upper/middle slope (100 $-700 \mathrm{~m}$ depth) from data collected in spring of 2007 during the "Mozambique 0307" bottom-trawl survey. A total of 129 hauls were performed following a random stratified sampling scheme in the different sectors and bathymetric strata. The biomass estimates were computed by the swept area method. Cephalopod species accounted for $8.4 \%$ of the total biomass captured, with a total of 50 species belonging to 13 families. The most important families in terms of species richness were Octopodidae and Sepiidae with 10 representatives each. The most abundant species was the omastrephid Nototodarus hawaiiensis, present in all sectors. The second most abundant species in terms of biomass was Sepia acuminata, followed by the Veladona togata (Octopodidae) mainly between 400 and $600 \mathrm{~m}$ depth. The highest biomass estimates were recorded in the sectors named Bazaruto B and Boa Paz, between 200 and $400 \mathrm{~m}$ depth. Species assemblages were analysed with the Bray-Curtis similarity index and the group average clustering method was applied, revealing three cephalopod assemblages : the shelf community $(100-200 \mathrm{~m})$, a wide transitional zone between shelf edge-upper slope $(200-600 \mathrm{~m})$ and the middle slope $(600-700 \mathrm{~m})$, mainly characterised by Sepia species, Nototodarus hawaiiensis, and Histioteuthis species, respectively. The diversity indices showed a higher diversity in Sofala, in the north of the study area, and in the shelf community in all sectors.
\end{abstract}

\section{INTRODUCTION}

The coast of Mozambique extends for $2,740 \mathrm{~km}$ and supports numerous fisheries that are very valuable, and mainly target crustaceans distributed over the continental shelf. Despite the importance of fisheries, the associated marine fauna are poorly known.
The first attempt to estimate the fish resources of Mozambique was made by Shomura et al.(1967) and Gulland, (1970). Later, Burczynski (1976) and Birkett (1978) presented some abundance estimates based on the swept-area method from fishery investigations along the coast of Mozambique on the $R / V$ Professor Mesyatsev. The Soviet trawler Aelita and the German Democratic Republic trawler Kattegat also carried out fishery investigations in Mozambican waters (Budnichenko, 1977; 
Anonymous, 1978). Finally, as a part of NORAD's long-term support of fisheries research and development in Mozambique, seven surveys with the $R / V$ Dr. Fridtjof Nansen were mounted over a period of about 14 years (Sætersdal et al., 1999). However, there is little information available about cephalopods from these surveys, and only related to some commercial species, and in some of these investigations sampled areas and gear differed.

More recently (March-April 1999), the Portuguese research vessel Capricornio carried out a trawl survey in Mozambique (Días et al., 1999) but cephalopods were not target species.

During March and April 2007 a research cruise ("Mozambique 0307") was conducted onboard the Spanish R/V Vizconde de Eza in order to assess the demersal resources as well as demersal species composition and distribution in the region down to $700 \mathrm{~m}$ depth. Data collected on these species allowed i) determination of the qualitative and quantitative composition of assemblages, ii) an analysis of their spatial distribution and iii) estimates of abundance of the most important species. The present work can be considered as the first major step towards increasing the knowledge of the cephalopods in Mozambique waters.

\section{MATERIAL AND METHODS}

The "Mozambique 0307" survey took place between 10th March and 11th April 2007. The study area extended from $26^{\circ} 50^{\prime} \mathrm{S}$ to $17^{\circ} \mathrm{S}$, covering the depth range between 100 and $700 \mathrm{~m}$ and a total area of $53,428 \mathrm{~km}^{2}$. The research vessel was the $R / V$ Vizconde de Eza, a stern trawler of $53 \mathrm{~m}$ length and 1,400 GRT, equipped with a standard Baka bottomtrawl, with a $52 \mathrm{~m}$ headline and $32 \mathrm{~m}$ footrope. The trawl had a stretched mesh of $46 \mathrm{~mm}$ in the codend and was covered internally with a $25 \mathrm{~mm}$ mesh liner. Gear performance and geometry during the fishing operations were monitored by a Simrad ITI sensors system. Mean headline height and mean wing spread were 1.9 and $20.0 \mathrm{~m}$, respectively.

For sampling purposes the area was divided into five geographical sectors, namely: 1 (Sofala), 2 (Bazaruto A), 3 (Bazaruto B), 4 (Boa Paz) and 5 (Inhaca). Five bathymetric strata were also considered within each of the sectors: A (100-200 m depth), B (200-400 m), C (400-500 m), D (500-
$600 \mathrm{~m})$ and $\mathrm{E}(600-700 \mathrm{~m})$ (see Figure 1). The geographical position of the fishing stations was selected according to a stratified random sampling scheme taking into account the above stratification. The number of hauls per geographic sector and depth strata was made proportional to the trawlable surface adjusted to the ship time available at sea, with coverage of around 2.44 hauls for every 1,000 $\mathrm{km}^{2}$. The duration of each haul was 30 minutes and were carried out during daylight at a mean towing speed of 3.0 knots. Catch values were standardized to number of individuals and biomass per 30 minutes of trawling by sectors and strata, for subsequent statistical analysis as described by Cochran (1971). The total biomass and the biomass by strata and sector were calculated using the swept area method (Sparre and Venema, 1997).

The identification of cephalopod assemblages was performed by calculating the transformed (double square root) Bray-Curtis similarity coefficient from the mean yields in weight of the hauls performed in each of the resulting sectorstratum combinations (i.e. $1 \mathrm{~A}, 1 \mathrm{~B}, 5 \mathrm{D}, 5 \mathrm{E}$ ) and the subsequent classification by cluster analyses applying the UPGMA linkage algorithm. The data matrix used comprised the sector-stratum combinations as cases (25 rows) and cephalopods species as variables (50 columns). The PRIMER software (Clarke \& Warwick, 1994) was used to calculate contribution of species to the similarity between groups. Diversity was assessed by estimation of the species richness (d) and the Shannon-Wiener (H) indices (Magurran, 1989).

\section{RESULTS AND DISCUSSION}

A total of 129 valid hauls were made during the cruise. Fish was the most important group with $87 \%$ of total estimated biomass. Almost all molluscs caught during the cruise were cephalopods. They were the second most important taxonomic group in the survey, with total catches of $3,615 \mathrm{~kg}$ which corresponded to 30,305 individuals. The estimated overall cephalopod biomass in the sampled area $(55,680$ tonnes) accounted for some $8 \%$ of the total biomass of all taxa (about 696,000 tonnes).

Cephalopods were quite ubiquitous and sometimes abundant in the catches. There were 50 species caught, from 13 taxonomic families (see Table 1). The most 


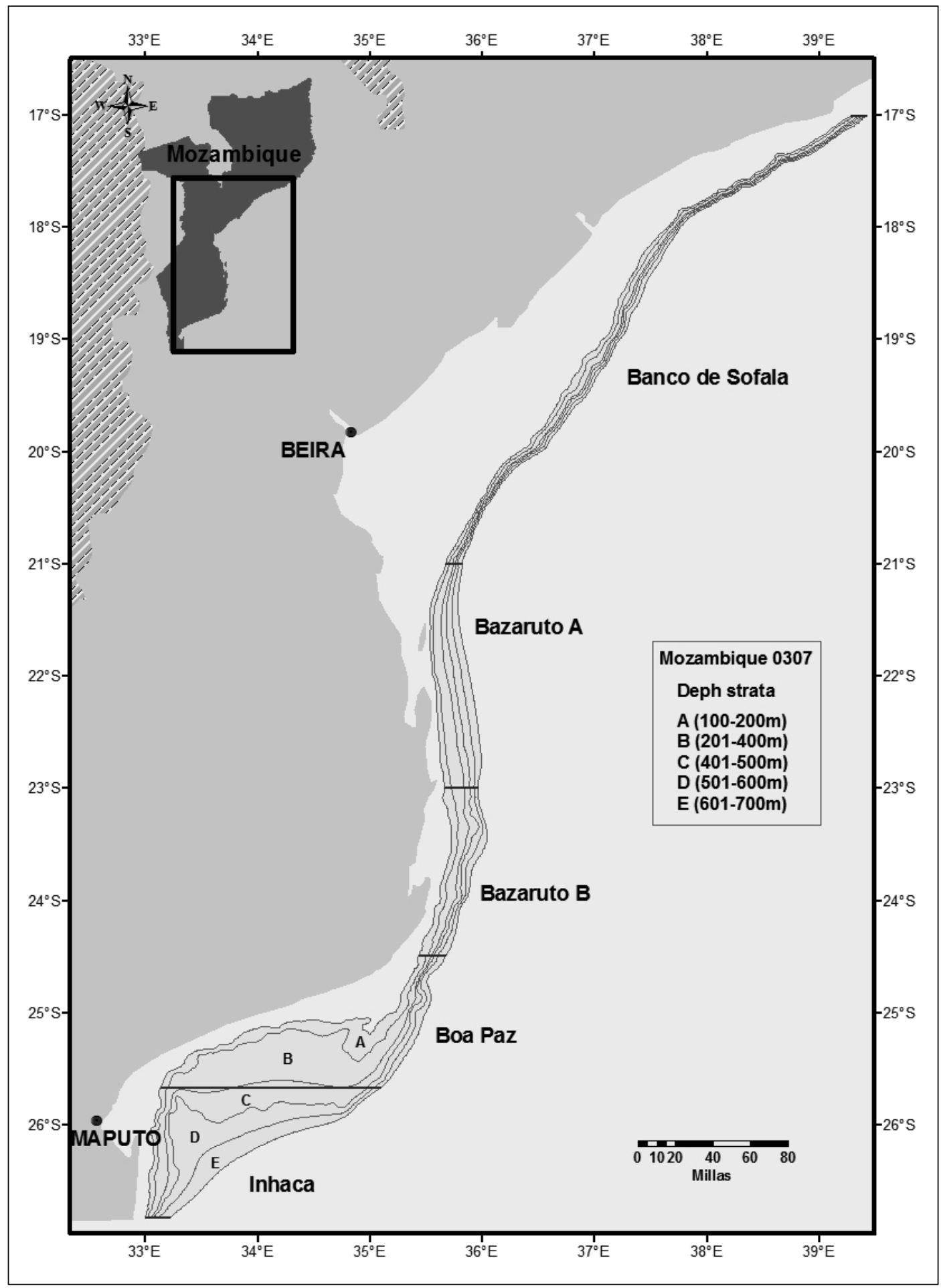

Fig. 1. The "Mozambique 0307" study area, showing the different strata and sectors sampled 
Table 1: Cephalopod species occurrence index by bathymetric stratum (A-E) and geographic sector (1-5) from the cruise "Mozambique 0307"

\begin{tabular}{|c|c|c|c|c|c|c|c|c|c|c|c|}
\hline \multicolumn{5}{|c|}{ BATIMETRIC STRATA } & SPECIES & \multirow[t]{2}{*}{ FAMILY } & \multicolumn{5}{|c|}{ GEOGRAFIC SECTORS } \\
\hline $\mathbf{A}$ & B & $\mathbf{C}$ & D & $\mathbf{E}$ & & & 1 & 2 & 3 & 4 & 5 \\
\hline & & & & & Amphitretus pelagicus & AMPHITRETIDAE & & & & & \\
\hline & & & & & Liocranchia reinhardti & CRANCHIIDAE & & & & & \\
\hline & & & & & Abralia $s p$ & ENOPLOTEUTHIDAE & & & & & \\
\hline & & & & & Enoploteuthis leptura & ENOPLOTEUTHIDAE & & & & & \\
\hline & & & & & Histioteuthis atlantica & HISTIOTEUTHIDAE & & & & & \\
\hline & & & & & Histioteuthis celetaria pacifica & HISTIOTEUTHIDAE & & & & & \\
\hline & & & & & Histioteuthis corona & HISTIOTEUTHIDAE & & & & & \\
\hline & & & & & Histioteuthis hoylei & HISTIOTEUTHIDAE & & & & & \\
\hline & & & & & Histioteuthis macrohista & HISTIOTEUTHIDAE & & & & & \\
\hline & & & & & Histioteuthis meleagroteuthis & HISTIOTEUTHIDAE & & & & & \\
\hline & & & & & Histioteuthis $s p$ & HISTIOTEUTHIDAE & & & & & \\
\hline & & & & & Loliginidae & LOLIGINIDAE & & & & & \\
\hline & & & & & Loligo reynaudi & LOLIGINIDAE & & & & & \\
\hline & & & & & Uroteuthis duvauceli & LOLIGINIDAE & & & & & \\
\hline & & & & & Uroteuthis edulis & LOLIGINIDAE & & & & & \\
\hline & & & & & Bathypolipus valdiviae & OCTOPODIDAE & & & & & \\
\hline & & & & & Benthoctopus unicirrhus & OCTOPODIDAE & & & & & \\
\hline & & & & & Benthostopus thielei & OCTOPODIDAE & & & & & \\
\hline & & & & & Donoctopus schmidti & OCTOPODIDAE & & & & & \\
\hline & & & & & Octopus aegina & OCTOPODIDAE & & & & & \\
\hline & & & & & Octopus defilippi & OCTOPODIDAE & & & & & \\
\hline & & & & & Octopus vulgaris & OCTOPODIDAE & & & & & \\
\hline & & & & & Pteroptopus sp. & OCTOPODIDAE & & & & & \\
\hline & & & & & Scaergus unicirrhus & OCTOPODIDAE & & & & & \\
\hline & & & & & Veladona togata & OCTOPODIDAE & & & & & \\
\hline & & & & & Eucleoteuthis luminosa & OMMASTREPHIDAE & & & & & \\
\hline & & & & & Nototodarus hawaiiensis & OMMASTREPHIDAE & & & & & \\
\hline & & & & & Ommastrephes bartramii & OMMASTREPHIDAE & & & & & \\
\hline & & & & & Ommastrephidae & OMMASTREPHIDAE & & & & & \\
\hline & & & & & Ornithoteutis volatilis & OMMASTREPHIDAE & & & & & \\
\hline & & & & & Todarodes angolensis & OMMASTREPHIDAE & & & & & \\
\hline & & & & & Todarodes filippovae & OMMASTREPHIDAE & & & & & \\
\hline & & & & & Moroteuthis aequatorialis & ONYCHOTEUTHIDAE & & & & & \\
\hline & & & & & Opisthoteuthis extensa & OPISTHOTEUTHIDAE & & & & & \\
\hline & & & & & Opisthoteuthis medusoides & OPISTHOTEUTHIDAE & & & & & \\
\hline & & & & & Psychroteuthidae & PSYCHROTEUTHIDAE & & & & & \\
\hline & & & & & Psychroteutis glacialis & PSYCHROTEUTHIDAE & & & & & \\
\hline & & & & & Sepia acuminata & SEPIIDAE & & & & & \\
\hline & & & & & Sepia australis & SEPIIDAE & & & & & \\
\hline & & & & & Sepia confusa & SEPIIDAE & & & & & \\
\hline & & & & & Sepia hieronis & SEPIIDAE & & & & & \\
\hline & & & & & Sepia incerta & SEPIIDAE & & & & & \\
\hline & & & & & Sepia joubini & SEPIIDAE & & & & & \\
\hline & & & & & Sepia prashadi & SEPIIDAE & & & & & \\
\hline & & & & & Sepia simoniana & SEPIIDAE & & & & & \\
\hline & & & & & Sepia $s p$ & SEPIIDAE & & & & & \\
\hline & & & & & Sepia vermiculata & SEPIIDAE & & & & & \\
\hline & & & & & Austrorosia mastigophora & SEPIOLIDAE & & & & & \\
\hline & & & & & Neorossia carolae & SEPIOLIDAE & & & & & \\
\hline & & & & & Spirula spirula & SPIRULIDAE & & & & & \\
\hline
\end{tabular}

important families in terms of species richness were Octopodidae and Sepiidae with ten representatives each. They were followed by Histioteuthidae and Ommastrephidae both of them represented by seven species, and Loliginidae by four species. The remaining families were represented by one or two species only (Figure 2a).
Regarding abundance in weight, Ommastrephidae was the most important family contributing a $78 \%$ to the total cephalopod biomass. Sepiidae and Octopodidae accounted for $12 \%$ and $6 \%$ respectively. Histioteuthidae and Loliginidae contributed $2 \%$ each and the remaining 8 families represented less than $1 \%$ (Figure 2b). Only seven 
a) In number of species

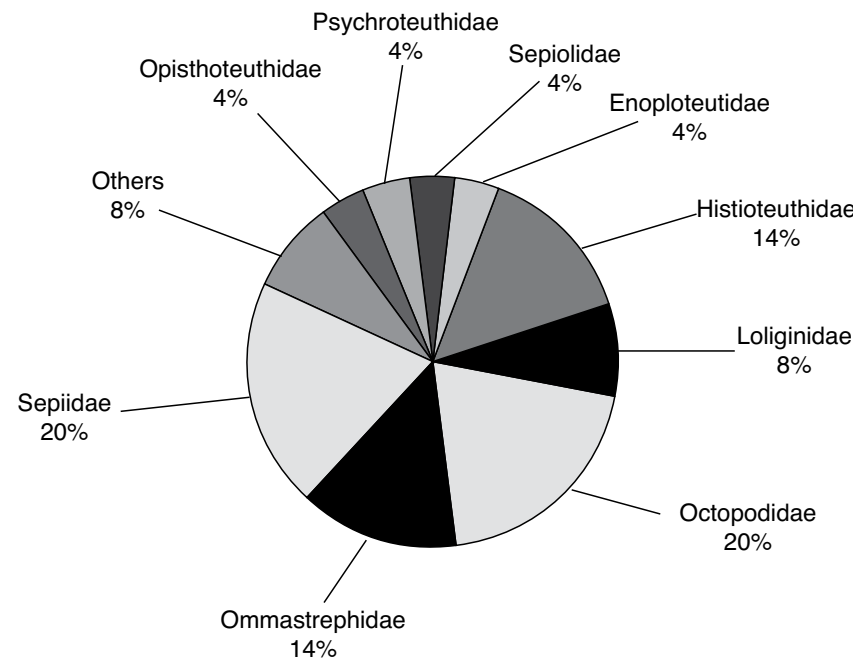

b) In total biomass

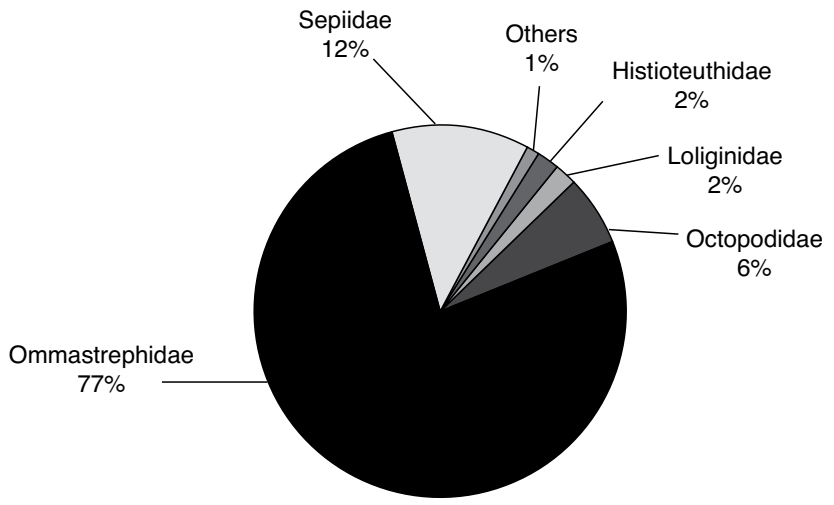

Fig. 2. Relative importance, in species number (a) and total biomass (b) of cephalopod families caught during the cruise "Mozambique 0307"

cephalopod species attained biomass estimates higher than 500 tonnes in the study area. They were: Nototodarus hawaiiensis (43,528 t), Sepia acuminata $(3,590 \mathrm{t})$, Veladona togata $(3,294 \mathrm{t})$, Sepia confusa (1,790 t), Histioteuthis celetaria $(1,134 \mathrm{t})$, Uroteuthis duvaceli $(567 \mathrm{t})$ and Sepia simoniana $(502 \mathrm{t})$. Their spatial distribution is represented in Figure 3a-f.

Table 1 also shows the occurrence indices by geographical sector and depth stratum of cephalopod species caught during the cruise. Some of the most common were also the most abundant. 
A
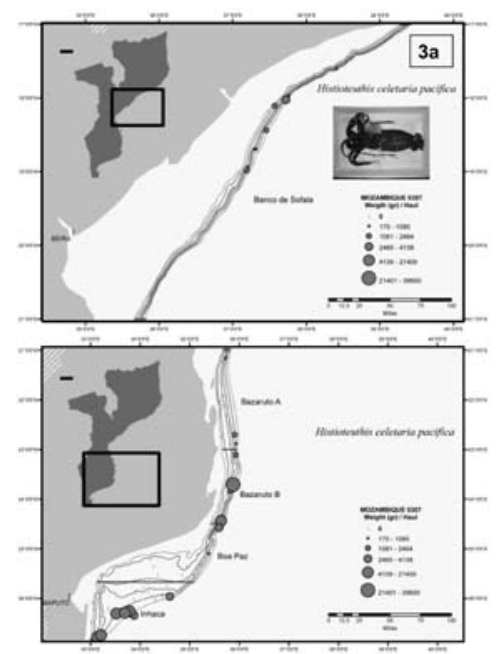

C
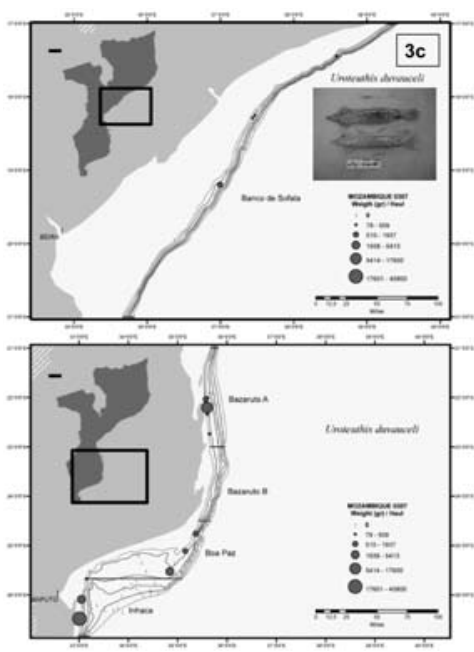

E
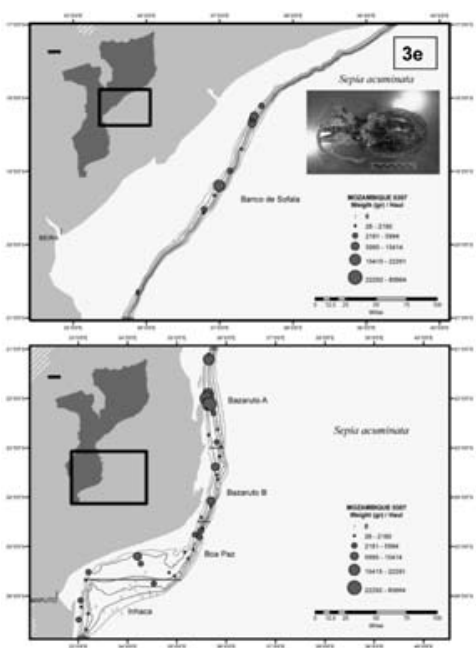

B
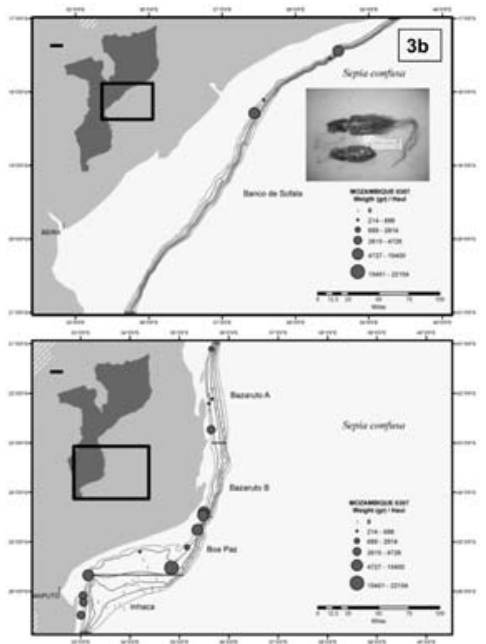

D
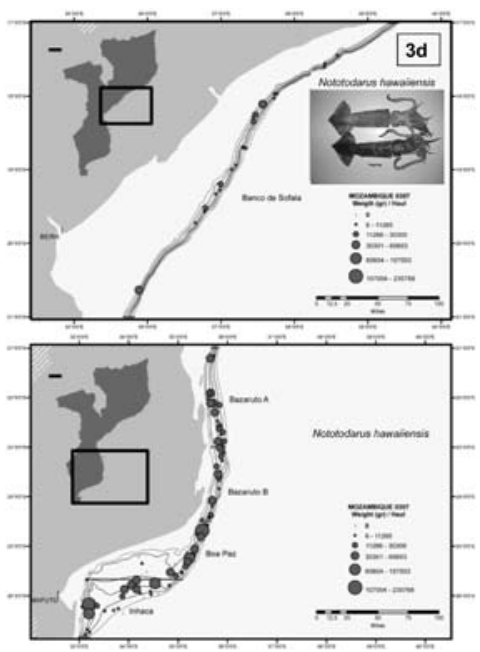

$\mathbf{F}$
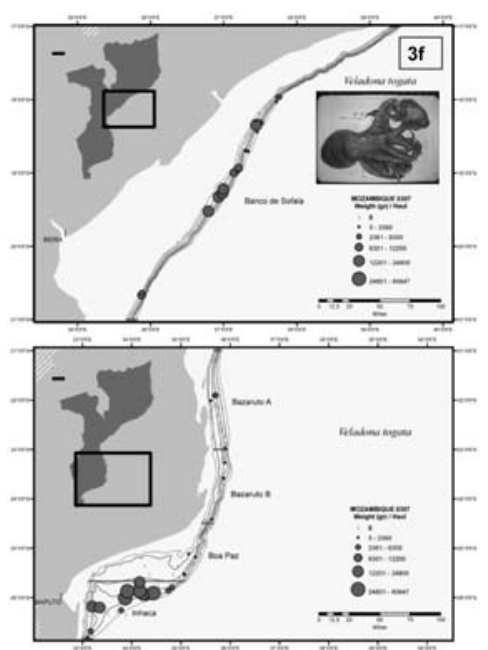

Fig. 3. Spatial distribution of abundance indices (grams/haul) of cephalopod species caught during the cruise "Mozambique 0307': a) Histiotheutis celetara pacifica; b) Sepia confusa, c) Uroteuthis duvauceli, d) Nototodarus hawaiiensis, e) Sepia acuminata and f) Veladona togata 


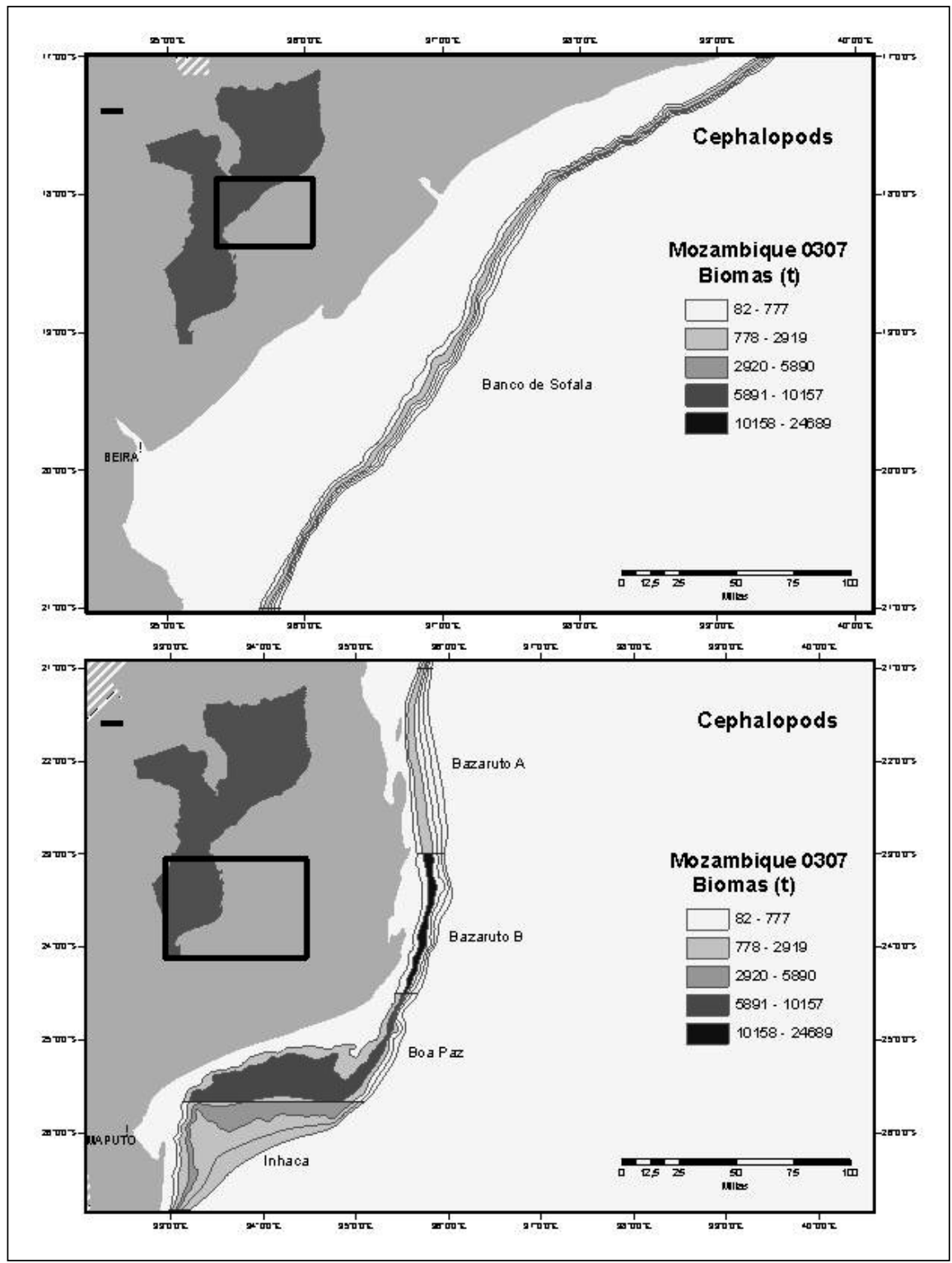

Fig. 4. Distribution by geographic sector and bathymetric stratum, of the total estimated biomass of cephalopods caught during the cruise Mozambique 0307

Nototodarus Hawaiians with an occurrence index of $75 \%$, S. acuminata with $43 \%$ and V. togata with $36 \%$, were present in all sectors and strata. Other common species such as $S$. confusa (occurrence index of $14 \%)$, H. celetaria $(21 \%)$, U. duvauceli $(12 \%)$ and $S$. simoniana $(7 \%)$ seem to have a more restricted distribution but forming concentrations of higher density.

For $S$. confusa, maximum depth range widens up to $450 \mathrm{~m}$ in contrast with the findings of Roeleveld,
(1972) and Roper \& Jereb (2005) recording this species to a maximum depth of $352 \mathrm{~m}$. Rare species like Amphitretus pelagicus, belonging to the only genus of the Amphitretidae family, have been found at depths greater than $500 \mathrm{~m}$, both in Sofala (1) and Inhaca (5) zones (Table 1).

Results from the cruise show that, despite all hauls being conducted from depths deeper than 100 m, a total of ten Sepia species were identified. Among them, Sepia acuminata was the second most 
abundant cephalopod species in the depth range between 100 and $500 \mathrm{~m}$ (see Table 1), greater than reports by Adams \& Rees (1966) and Roper \& Jered (2005) who found this species at a maximum depth at $369 \mathrm{~m}$.

These results also increase the geographic range into the Western Indian Ocean of Todarodes filippovae, a species described by Adam (1975), that shows a circumpolar distribution in the Southern Ocean up to $35^{\circ} \mathrm{S}$ (Nesis, 1982; Roper, 1984). The capture of one specimen in the deepest stratum $(\mathrm{D}, 600-700 \mathrm{~m})$ in the Inhaca zone extends the range of the species northwards (to $26^{\circ} \mathrm{S}$ ) in deep zones of the continental slope, greater even than the maximum depth of $500 \mathrm{~m}$ cited by Roper et al, (1984).

The genus Pteroctopus, with one specimen captured in Boa Paz (4) zone, was not previously recorded from Mozambique waters. P.tetracirrhus is a Mediterranean species whose characteristics are close to those of the captured specimen. The possibility of a Lessepsian migration (across the Suez Canal) could be considered, because other cases are reported, as for Sepiola steenstrupiana described by Rocha et al. (1998) from Somali waters. However, the specimen of Pterotopus awaits full analysis in order to confirm identification.

The distribution of total estimated biomass of cephalopods by geographic sector and bathymetric stratum shows that the highest values are found in the sectors Bazaruto B and Boa Paz, between 200 and $400 \mathrm{~m}$ depth, the former yielding the greatest abundance with a calculated biomass ranging from 5,871 to 10,157 tonnes (Figure 4). Comparative analyses of cephalopod trends in abundance (individuals $\left./ \mathrm{km}^{2}\right)$, biomass $\left(\mathrm{kg} / \mathrm{km}^{2}\right.$ ) and mean individual weight $(\mathrm{kg})$ in relation to depth indicate that the highest concentrations of this fauna in the

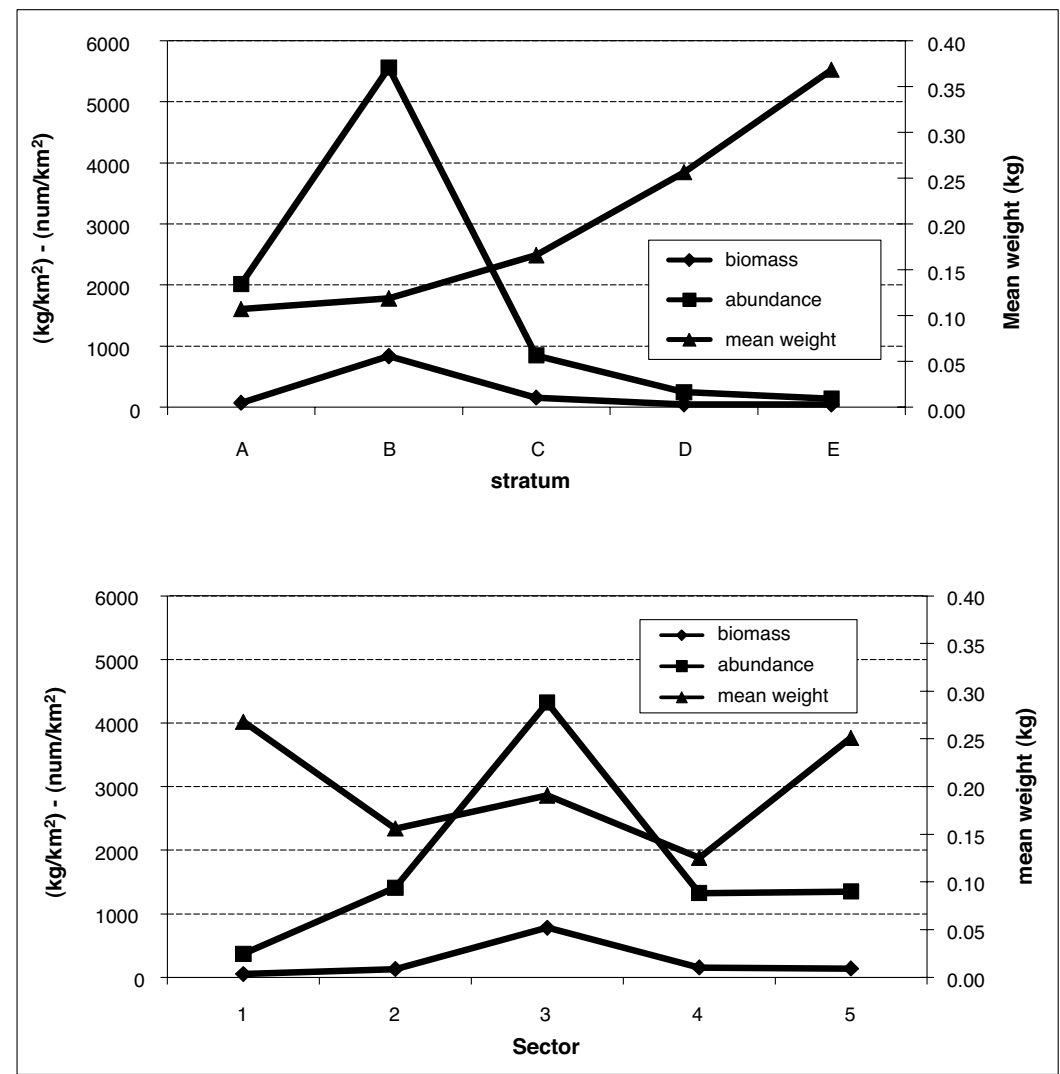

Fig. 5. Trends in abundance (individual numbers $\left./ \mathrm{km}^{2}\right)$, biomass $\left(\mathrm{kg} / \mathrm{km}^{2}\right)$ and mean individual weight $(\mathrm{kg})$ in relation to depth and to bathymetric stratum of cephalopod species caught during the cruise "Mozambique 0307". Sectors: 1 - Sofala; 2 - Bazaruto; 3 - Bazaruto B; 4 - Boa Paz; 5 - Inhaca; Strata: A- 100-200m; B - 200-400m; C - 400-500m; D - 500-600m; E-600-700m 


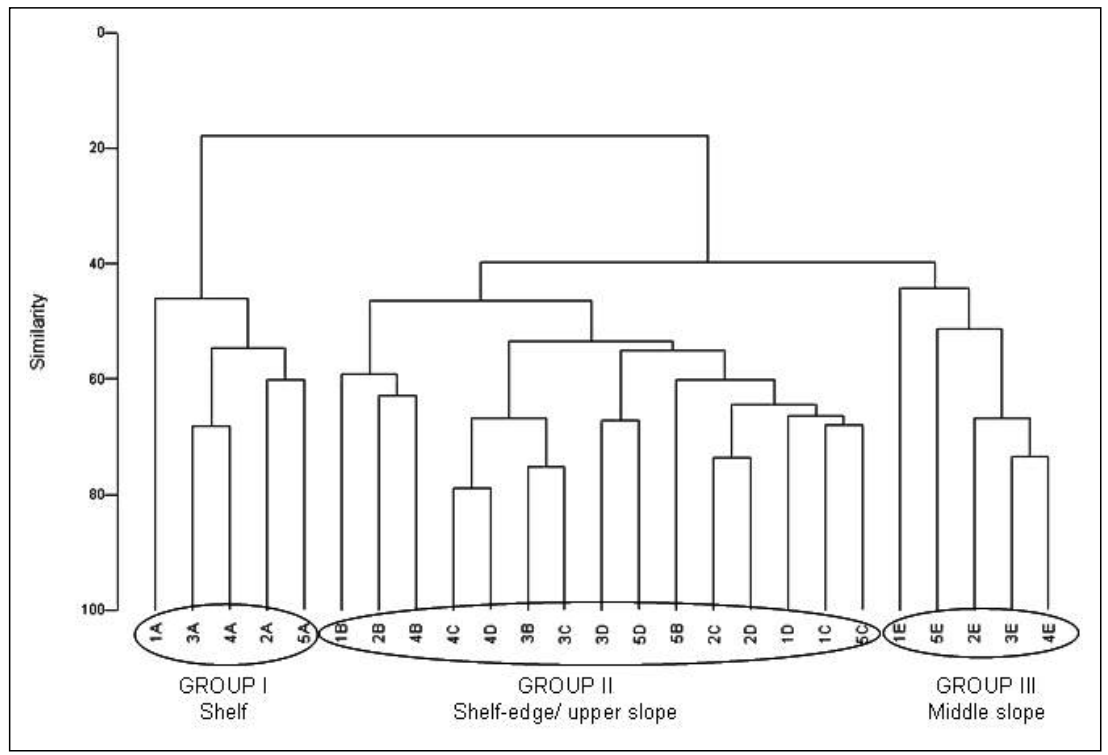

Fig. 6. Dendrogram from cluster analysis showing similarities between average hauls (by sector and strata) based on the composition and abundance of cephalopod species in the "Mozambique 0307" survey

Table 2: Average abundance in grams/haul (Av. Abund.), average similarity (Av Sim.), ratio (Sim/SD), percentage contribution to the grouping and cumulative percentage of each species to each group obtained from the SIMPER analysis of the Mozambique 0308 cruise

\begin{tabular}{|c|c|c|c|c|c|}
\hline \multicolumn{6}{|c|}{ Continental shelf group (I), Average similarity: $\mathbf{5 3 . 0 5}$} \\
\hline Species & Av. Abund & Av. Sim & Sim/SD & Contrib\% & Cum. \% \\
\hline Sepia confusa & 5487.71 & 15.53 & 3.94 & 29.27 & 29.27 \\
\hline Se pia simoniana & 2691.24 & 10.91 & 3.50 & 20.56 & 49.84 \\
\hline Uroteuthis duvauceli & 4401.57 & 6.00 & 1.11 & 11.31 & 61.15 \\
\hline Sepia acuminata & 1211.80 & 4.93 & 1.07 & 9.30 & 70.45 \\
\hline Sepia vermiculata & 1583.53 & 4.58 & 0.96 & 8.63 & 79.07 \\
\hline Uroteuthis edulis & 479.29 & 2.61 & 0.62 & 4.91 & 83.99 \\
\hline Nototodarus hawaiiensis & 282.20 & 2.38 & 0.91 & 4.48 & 88.47 \\
\hline \multicolumn{6}{|c|}{ Shelf edge -upper slope group (II) Average similarity: 54.03} \\
\hline Species & Av. Abund & Av. Sim & Sim/SD & Contrib\% & Cum. \% \\
\hline Nototodaus hawaiiensis & 25539.4 & 23.03 & 3.22 & 42.64 & 42.64 \\
\hline Sepia acuminata & 4724.46 & 8.48 & 1.55 & 15.70 & 58.33 \\
\hline Austrorosia mastigophora & 281.31 & 7.10 & 2.16 & 13.14 & 71.47 \\
\hline Veladona togata & 3796.44 & 5.69 & 1.01 & 10.52 & 82.00 \\
\hline Histioteuthis corona & 175.33 & 2.50 & 0.66 & 4.63 & 86.63 \\
\hline Neorossia carolae & 108.77 & 2.23 & 0.69 & 4.13 & 90.76 \\
\hline \multicolumn{6}{|c|}{ Middle slope group (III), Average similarity: 53.75} \\
\hline Species & Av. Abund & Av. Sim & Sim/SD & Contrib\% & Cum. \% \\
\hline H. celetaria pacifica & 5525.25 & 14.94 & 4.96 & 27.80 & 27.80 \\
\hline Nototodarus hawaiiensis & 5497.62 & 13.63 & 2.29 & 25.35 & 53.15 \\
\hline Histioteuthis corona & 659.59 & 10.03 & 8.04 & 18.66 & 71.81 \\
\hline Ommastrephidae & 206.75 & 5.06 & 1.13 & 9.40 & 81.21 \\
\hline Neorossia carolae & 123.19 & 3.93 & 1.13 & 7.31 & 88.53 \\
\hline Austrorosia mastigophora & 54.56 & 3.87 & 1.10 & 7.19 & 95.72 \\
\hline
\end{tabular}


area are located between 200 and $400 \mathrm{~m}$ (Figure 5) and seem to prove that large individuals tend to distribute in deeper waters. By geographical sector, Bazaruto B shows the highest abundance and mean biomass, with the largest individual weights in Sofala and Inhaca sectors (Figure 5).

The cluster analysis carried out in order to identify cephalopod assemblages indicated three groups, with $46 \%$ of similarity (Figure 6 ). These ones were: I- "stratum 1 in all sectors", II - "strata 2,3 and 4 in all sectors" and III - "stratum 5 in all sectors". Similarity inside group I is mostly contributed by S. confusa (29\%) and S. simoniana (21\%), while in group III species of the genus Histiotheutis are the major contributors to group similarity, notably $H$. celetaria and $H$. corona with $27.8 \%$ and $18.7 \%$, respectively, and the ommastrephid Nototodarus hawaiiensis with $25.3 \%$. And finally, inside group II Nototodarus hawaiiensis sustains the similarity inside the group with $42.6 \%$, followed by $S$. acuminata $(15.7 \%), A$. mastigophora (13.4\%) and the octopus $V$. togata (10.5\%) (Table 2).

These three cephalopod species assemblages correspond to the bathymetric zones, being continental shelf (I), shelf edge-upper slope (II) and middle slope (III) communities. Unlike depth, latitude does not seem to have influence on the spatial distribution of the species, a feature reported by Quetglas et al. (2000) and González \& Sánchez, (2002) for the Mediterranean. Smale et al. (1993), analyzing the fishes and cephalopods communities

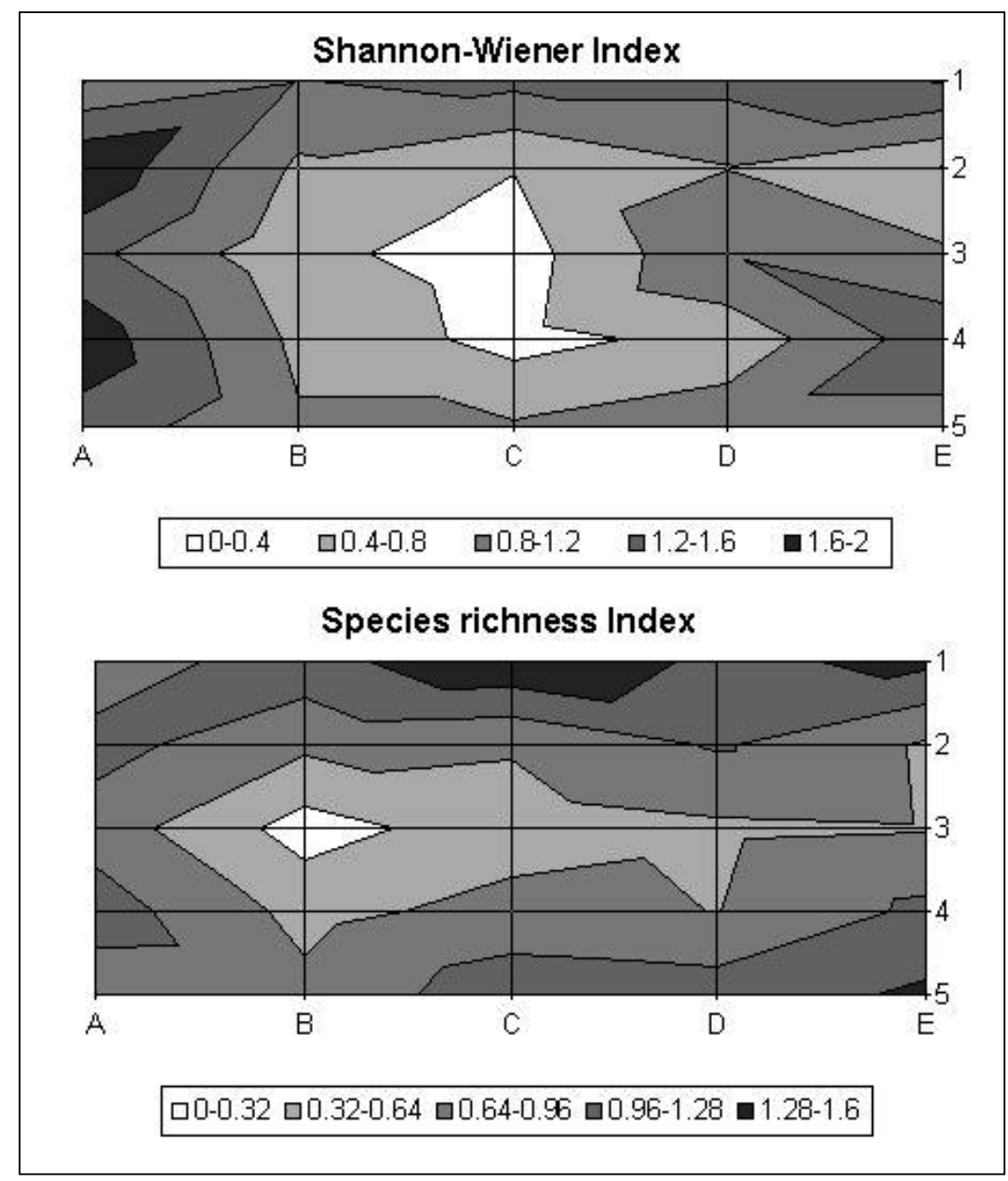

Fig. 7. Representation of the Shannon-Wiener (H) and the species richness (d) diversity indices estimates by sectors and strata 
in a near zone (Agulhas Bank, South Africa), concluded that apart from depth, temperature and oxygen concentration have an influence on the distribution of species, though in their study cephalopods were poorly represented.

The diversity indexes (Shannon-Wiener $(\mathrm{H})$ and species richness (d)) show different values in relation to the geographic zones (1-5) and depth strata (A-E), as seen in Figure 7. The highest diversity was found in Sofala (1) followed by Inhaca (5). With respect to bathymetric strata, the highest diversity value was obtained for the inshore stratum (100-200 m), followed by the deepest stratum. The lowest diversity occurs in the middle slope (C stratum) and in the central zone of the surveyed area (Bazaruto B) which shows, on the other hand, the highest abundance (Figure 7). This area is dominated by few species but of very high abundance in some cases, like Nototodarus hawaiiensis with a maximum yields in this stratum and zone. Regarding the geographical distribution of this species, Nesis (1984) firstly suggested the possibility of the occurrence in the western Indian Ocean either of a new subspecies of $N$. sloani.or even a new species of this genus. Later, this same author (Nesis, 1986) and Dunning and Förch (1996) confirmed the presence the $N$. hawaiiensis in this area of the Indian Ocean. Probably, those squids recorded in southern African (Agulhas Bank) by Smale et al. (1993) as Nototodarus sp. could also belong to $N$. hawaiiensis. This species has not been recorded in the Atlantic coast of southern Africa (Sánchez, 1998; Villanueva and Sánchez, 1993).

This first study on Mozambican cephalopods revealed a high diversity among this faunistic group in this zone of the Indian Ocean. Results suggest further research is needed to increase our knowledge and understanding of this group, especially in view of their role in the ecosystem's food chain, their fishery potential, and the abundance estimates for some of the species found.

Acknowledgments - The authors are grateful to Dr. Francisco Rocha and Dr. Chingis Nigmatullin for his help in some species identification. Our thanks to the crew of V/O Vizconde de Eza for their work and proficiency, as well as to the rest of colleagues of the Instituto Español de Oceanografía and the
Instituto de Investigaçao Pesqueira of Mozambique that participated in the survey.

\section{REFERENCES}

Adam, W \& Ree, W.J. (1966). A review of the cephalopod family Sepiidae. Scientific Reports of the John Murray Expedition 1933-1934, 11(1): 1-165.

Anonymous. (1978). Report on the test fishing trip of the freezer trawler "Kattegat" in the waters of the People's Republic of Mozambique from October 2 to December 12, 1977. Institute of Deep-Sea Fishery and Fish processing. Rostock, German Democratic Republic.

Birkett, L. (1978). Western Indian Ocean Fishery Resources Survey. Report on the cruises of R/V PROFESSOR MESYATSEV December 1975June 1976/July 1977-December 1977. Indian Ocean Program FAO Technical Report no. 21. FAO, Rome.

Budnichenko, V. A. (1977). Results obtained from the "Aelita" exploratory surveys undertaken in the shelf and open waters continuous to the coast of the People's Republic of Mozambique (May 1976 through August 1977). Final Report Azcher-NIRO.

Burczynski, J. 1976. Echo survey along the East African coast from Mombasa to Laurence Marques by R/V PROFESSOR MESYATSEV in JanuaryFebruary 1976. FAO Fisheries Travel Report and Aide Memoire no 12, Rome 1976.

Clarke \& Warwick, R.M. (1994). Change in marine communities: an approach to statistical analysis and interpretation. Natural Environment Research Council, UK, 144P.

Cochran, G. (1971). Técnicas de muestreo. Compañía Editorial Continental, México City.

Días, M. L., Neves dos Santos, M., Pinto, M. A., Jardim, E., Rodrigues, M. J., Santos, A. \& Dove, V. (1999). Relatório da $1^{\circ}$ Campanha de Investigaçao Pesqueria Luso-Moçambicana do “NICAPRICÓRNIO” nas Águas de Moçambique. Final Report IPIMAR/IIP.

Dunning M.C. and Förch E.C. (1998). A review of the systematics, distribution, and biology of arrow squids of the genus Nototodarus Pfeffer, 1912 (Cephalopoda: Ommastrephidae). Smithsonian Contributions to Zoology 586: 393-404.

González M. \& Sánchez, P. (2002). Cephalopod assemblages caugth by trawling along the Iberian Peninsula Mediterranean coast. Sci. Mar., 66 (Suppl. 2): 199-208.

Gulland, J. A. (1970). The fish resources of the ocean. FAO Fish. Tech. Pap. (97): 425 p. 
Magurran, A. (1989). Diversidad ecológica y su medición. Ed. Vedrá, Barcelona, 200p.

Nesis, K. N. (1982). Cephalopod of the world: squids, cuttlefishes, octopuses and their allies. Neptune City, New Jersey, T.F.H. Publications Inc. Ltd., $351 \mathrm{pp}$.

Nesis, K.N., 1986. Cephalopods from the Seamounts of the Western Indian Ocean. Okeanologiya, 26(1): 123-130.

Quetglas, A., A. Carbonell \& Sánchez, P. (2000). Demersl Continental Shelf and Upper Slope Cephalopod Assemblages from the Balearic Sea (North-Western Mediterranean). Biological Aspects of Some Deep-sea Species. Est. Coast. Shelf Sci., 50: 739-749.

Rocha, F., Fuentes, L., Guerra, A. \& Sainza, M.C. (1998). Cephalopods of Somalia. Iberus , 16(2): 129-142.

Roeleveld, M.A. (1972). A review of the Sepiidae (Cephalopoda) of southern Africa. Annals of the South African Museum, 59(10): 193-313.

Roper,C.F.E.\& Jered,P.(2005).FAO Species Catalogue for Fisheries Purposes $N^{\circ} 4$. Cephalopods of the World: An annotated and illustrated catalogue of cephalopod species known to date. Vol. 1, Chambered Nautiluses and Sepioids. 262 pp.

Roper, C.F.E., Sweeney, M.J. \& Nauen, C.E. (1984). FAO Species Catalogue. Vol3. Cephalopod of the World. An annotated and illustrated catalogue of species of interest to fisheries. FAO Fisheries Synopsis, 125(3): 277 pp.
Sætersdal, G., G. Bianchi, T. Strømme \& Venema, S. C. (1999). The DR. FRIDTJOF NANSEN Programme 1975-1993. Investigations of fishery resources in developing countries. History of the programme and review of results. FAO Fisheries Technical Paper $n^{\circ} .391$. FAO, Rome.

Sanchez, P. (1998). Systematic and distribution of the cephalopods of Namibia. Monogr. Zool. Mar., 3: 205-266.

Shomura, R.S., D. Menasveta, A. Suda and F. Talbot, 1967. The present status of fisheries and assessment of potential resources of the Indian Ocean and adjacent seas. Report of the IPFC group of experts on the Indian Ocean. FAO Fish. Rep. (54): $32 \mathrm{p}$.

Smale, M.J., Roel, B.A., Badenhorst, A. \&. Field, G. (1993). Analysis of the demersal community of fish and cephalopods on the Agulhas Bank, South Africa. Journal of Fish Biology, 43 (Supplement A): $169-191$.

Sparre, P. \& Venema, S.C. (1997). Introduction to tropical fish stock assessment. Part 1. Manual. FAO Fisheries Technical Paper. № 306.1, Rev. 2.: 420pp.

Villanueva, R. \& Sánchez, P. (1993). Cephalopods of the Benguela Current off Namibia: new additions and considerations on the genus Lycoteuthis. Journal of Natural History, 27: 15-46. 